\title{
Rapid molecular detection of Candidatus Liberibacter asiaticus, the bacterium associated with citrus huanglongbing (greening) disease of Mandarin using polymerase chain reaction
}

\author{
M. V. Mahajan, G. P. Jagtap* and Utpal Dey \\ Department of Plant Pathology, Marathwada Krishi Vidyapeeth, Parbhani, Maharashtra, India. \\ Accepted 5 July, 2013
}

\begin{abstract}
Huanglongbing (HLB or citrus greening or yellow shoot disease) is a devastating disease of citrus caused by nonculturable, fastidious phloem limited bacterium, Candidatus Liberibacter asiaticus and threatens the citrus industry in Asian countries. The putative causal agent of the disease is transmitted through insect vector or grafting with diseased budwood. The polymerase chain reaction (PCR) diagnosis is a more reliable and sensitive diagnostic tool for detecting greening bacterium than other conventional approaches like electron microscopy, DNA-DNA hybridization and immunofluorescence (IF) for detection of citrus greening. Results reveal that sodium sulphite method of DNA isolation provided higher yield and better quality DNA than other methods. To confirm the reliability of PCR, the greening bacterium was also detected in graft-inoculated plants, which showed typical greening symptoms. Results show amplification of $450 \mathrm{bp}$ in PCR suggesting sampling in March is more suitable for PCR detection of greening bacterium. The methods validated in this study will be very useful for regulatory response, effective management of infected trees, and development of a Candidatus Liberibacter asiaticus free nursery system.
\end{abstract}

Key words: Citrus greening, huanglongbing (HLB), molecular detection, polymerase chain reaction (PCR), phloem-limited bacterium.

\section{INTRODUCTION}

Citrus belongs to the family Rutaceae and is the third important fruit crop of India after banana and mango with the acreage of 5.63 lakh ha and production of 56.8 lakh tons and average productivity of $10.1 \mathrm{t} / \mathrm{ha}$. The most important commercial citrus cultivars in India are, the mandarin (Citrus reticulata Blanco), followed by sweet orange (Citrus Sinensis osbeck) and acid lime (Citrus aurantifolia Swingle) sharing 65, 25 and $10 \%$, respectively, of all citrus fruits produced in the country. The state of Maharashtra is considered as the top most citrus growing state in terms of area (2.38 lakh ha), second in terms of production (14.4 lakh tones) and $10^{\text {th }}$ in terms of productivity $(6.0 \mathrm{t} / \mathrm{ha})$ according to Indian Horticulture Database, 2005.

In India, the major pathogens of economic importance in citrus are citrus tristeza virus (CTV), citrus yellow

*Corresponding author. E-mail: drgpjagtap@gmail.com.

Abbreviations: CTV, citrus tristeza virus; CYMV, citrus yellow mosaic badna virus; ICRSV, indian citrus ring spot virus; CGB, citrus greening bacterium; CTAB, cetyl trimethyl ammonium bromide. 
mosaic badna virus (CYMV), indian citrus ring spot virus (ICRSV), viroids diseases like citrus exocortis viroid and a fastidious prokaryote causing citrus greening disease. Citrus greening disease is an important disease of citrus which greatly affects the production of citrus fruits in several parts of India (Ahlawat, 1997). In India, the greening disease was first identified by L.R. Fraser in 1965 and its wide spread occurrence was confirmed by Varma et al. (1993) and Ahlawat and Pant (2003).

Confirmation that a citrus tree is affected by greening has up to now relied on the electron microscopical identification of the bacterium, but due to erratic distribution of the pathogen in sieve tubes, it was cumbersome process to cut the right tissue having greening bacterium. However, several indirect approaches such as biological indexing, immunofluorescence tests with monoclonal antibodies and DNA-DNA hybridization with radioprobes have been used for greening diagnosis (Ahlawat and Pant, 2003). Biological indexing is a time consuming procedure and temperature dependent. It requires a well-equipped glass houses and long term maintenance of indicator hosts. The use of monoclonal antibodies for field diagnosis has proven unsatisfactory (Korsten et al., 1993). Detection by DNA probes, though an accurate method for detection requires handling of radioactive elements and is being discouraged. Moreover, these are not practically feasible methods for handling a large sampling unit. The recent study by Hocquellet et al. (2000) and Ahlawat et al. (2003) showed that gene amplification of $\beta$ operon ribosomal protein is a sensitive and promising technique for the detection and differentiation of greening bacterium. The disease/bacterium cannot be diagnosed at ease by conventional procedures viz., electron microscopy examination of ultra thin sections, bioassay on indicator plants. Therefore, the present study was attempted with a view to develop an alternative, rapid, reliable and cost effective detection protocol employing polymerase chain reaction (PCR). However more work is required for standardization of detection of greening organism PCR and its application on large scale.

\section{MATERIALS AND METHODS}

\section{Source of samples}

The three trees showing typical symptoms of greening were identified and labeled. The symptomatic leaves from individual tree were taken as source material for extraction of DNA and confirmation of infection by PCR as described by Ahlawat et al. (2003).

\section{Graft transmissible rootstock}

The scions from these six trees were grafted on mandarin in the glasshouse. The observation for symptoms development in grafted plants was taken periodically and finally grafted plants were tested using PCR.

\section{DNA extraction from citrus tissue}

The total DNA was isolated from midrib and petiole of symptomatic leaves of infected field trees. Three methods of DNA extraction viz. DN-easy Plant Mini kit (QIAGEN, Germany), sodium sulphite (Baranwal et al., 2003), nucleic acid technique were employed.

\section{DNA extraction protocol by commercial kit (QIAGEN DN-easy Plant Mini kit)}

150 leaves of greening infected midrib were ground in liquid nitrogen in sterilized pestle and mortar. The tissue powder was transferred into $1 \mathrm{ml}$ eppendorf tube. The DNeasy membrane and it was incubated for $5 \mathrm{~min}$ at room temperature and centrifuged for 1 $\mathrm{min}$ at $6000 \mathrm{rpm}$. The above step was repeated. DNA was isolated according to Qiagen's manual.

DNA extraction by sodium sulphite method (Baranwal et al., 2003)

$10 \mathrm{ml}$ extraction buffer was prepared (Appendix) in a single Mortar and pestle. $10 \mathrm{ml}$ extraction buffer was heated to $65^{\circ} \mathrm{C}$ before adding to powdered tissue. The powdered tissue was taken into 1.5 eppendorf tube. $1 \mathrm{ml}$ hot extraction buffer was added. The eppendorf tube containing powdered tissue in extraction buffer was kept at $95^{\circ} \mathrm{C}$ heating block for $10 \mathrm{~min}$. Regular vortexing after every 2 min was done and kept on ice for $2 \mathrm{~min}$. The tube was centrifuged at $12000 \mathrm{rpm}$ for $5 \mathrm{~min}$. Approximately, $800 \mu \mathrm{l}$ of supernatant was taken and transferred to new tube containing $5 \mu \mathrm{l}$ of RNase and incubated at $37^{\circ} \mathrm{C}$ for $20 \mathrm{~min} .480 \mu \mathrm{l}$ of isopropanol was added to it and mixed by gentle rocking. The tube was centrifuged for 5 min at $12000 \mathrm{rpm}$. To the pellet, $30 \mu \mathrm{l}$ of sterile distilled water was added. To dissolve, DNA pellet with distilled water was heated briefly at $50^{\circ} \mathrm{C}$ and flicking was done. The DNA was precipitated with $30 \mu \mathrm{l}$ of $3 \mathrm{M}$ solution acetate and $1 / 10^{\text {th }}$ volume of $95 \%$ ethanol. The tube was kept on ice-for 10 to $20 \mathrm{~min}$. The tube was centrifuged for 5 min with $12000 \mathrm{rpm}$. The ethyl alcohol was poured off. The pellet was dried for $40 \mathrm{~min}$ at $37^{\circ} \mathrm{C}$. The pellet was dissolved in 70 to 100 $\mu \mathrm{l}$ of double distilled water, reheated at 45 to $50^{\circ} \mathrm{C}$.

DNA extraction using membrane bard nucleic acid technique (Baranwal et al., 2003)

$100 \mathrm{mg}$ of petiole and midrib of leaves tissue from las infected plant were taken and homogenized in $1 \mathrm{ml}$ of alkaline solution of $\mathrm{NaOH}$. The resulted extract were incubated at room temperature $\left(24-32^{\circ} \mathrm{C}\right)$ for $15 \mathrm{~min}$ or centrifuged at $1200 \mathrm{~g}$ for $10 \mathrm{~min}$. $5 \mu \mathrm{l}$ of sap were spotted on untreated NCM5 (BAS 85, poresize $0.45 \mu \mathrm{m}$ Scwicher and Schuee, Kece, N.H.) that were dried for $30 \mathrm{~min}$ at 24 to $32^{\circ} \mathrm{C}$. Individual spot $(4.0 \mathrm{~mm})$ for each sample were cut out with paper hole punch (Kangaro industries, Ludhiana, India) and eluted in $30 \mu \mathrm{l}$ of sterile distilled water by incubation at $80^{\circ} \mathrm{C}$ for $10 \mathrm{~min}$ on a heat block. The liquid was collected by centrifugation (termed NCM eluted extract). Volumes of 2.5, 5, 10 and $20 \mu \mathrm{l}$ were used for detection of cla ANAs by PCR.

\section{Primer synthesis}

Pair of primers from conserved region of ribosomal $\beta$-operon gene and ribosomal DNA was synthesized and used to detect citrus greening bacterium in PCR system (CG3450F) primer (Table 1).

\section{Polymerase enzyme}

Polymerase enzyme (Taq polymerase) was evaluated for their 
Table 1. Specific primers used for amplification of ribosomal $\beta$-operon gene and $16 \mathrm{~s}$ ribosomal DNA of citrus greening bacterium.

\begin{tabular}{clcc}
\hline Primer & Primer sequence & $\begin{array}{c}\text { Annealing } \\
\text { temperature }\left({ }^{\circ} \mathrm{C}\right)\end{array}$ & $\begin{array}{c}\text { Amplicon size } \\
(\mathrm{bp})\end{array}$ \\
\hline A & $\begin{array}{l}\text { 5'GCGCGTATCCAATACGAGCGGCA3' } \\
\text { 5'GCCTCGCGACTTCGCAACCCAT3' }\end{array}$ & 62 & 1160 \\
B & $\begin{array}{l}\text { 5'TATAAAGGTTGACCTTTCGAGTTT3' } \\
\text { 5'ACAAAAGCAGAAATAGCAAACA3' }\end{array}$ & 58 & 703 \\
C & 5'TGGGTGGTTTACCATTCAGTG3' & & 450 \\
\hline
\end{tabular}

efficiency to amplify and it was used with primer to compare their efficacy.

\section{PCR amplification}

The amplification was performed on a thermal cycle (manufacture) using primer and polymerase enzyme (Taq) for comparing their efficiency in amplification of DNA of greening bacterium based on the number of sample amplified and intensity of amplified DNA band. The conditions followed for PCR are as follows: Initial denaturation was given at $94^{\circ} \mathrm{C}$ for $5 \min 1$ cycle followed by denaturation at $94^{\circ} \mathrm{C}$ for $30 \mathrm{~s}$, annealing at $60^{\circ} \mathrm{C}$ for $30 \mathrm{~s}$ and extension at $72^{\circ} \mathrm{C}$ for $1 \mathrm{~min}$ and the final extension was given at $72^{\circ} \mathrm{C}$ for $10 \min 30$ cycles.

\section{Analysis of PCR product by electrophoresis}

Following PCR, amplicon were analyzed in 1\% agarose gel and electrophoresed in Tris-acetate ethylenediaminetetraacetic acid (EDTA) (TAE) buffer containing ethidium bromide; $0.5 \mathrm{~g}$ agarose was melted in $50 \mathrm{ml} \mathrm{1x}$ TAE running buffer and $2 \mu \mathrm{l}$ ethidium bromide was added to it after cooling to around $50^{\circ} \mathrm{C}$ and poured into a casting tray for polymerization placing the 12 well comb. The comb was removed after polymerization and the gel was then placed on electrophoresis tray filled with $1 \times$ PAE buffer $20 \mu \mathrm{l}$ each of PCR product mixed with $2 \mu \mathrm{l}$ of $6 \mathrm{x}$ loading dye was loaded into the well and was run at $60 \mathrm{~V}$ for $30 \mathrm{~min}$. An aliquot of $1 \mathrm{~kb}$ DNA ladder $4 \mu \mathrm{l}$ was named with dye similarly and electrophoresed to serve as molecular weight marker. After the run, the gel was observed under ultraviolet (UV) transillumina and photographed on thermal paper using gel documentation system.

\section{Validation of PCR for detection of greening bacterium}

Following the standardization of DNA extract method, primer and enzyme was validated by taking 40 random sample collection from the apparently infected mandarin trees in orchard.

\section{RESULTS AND DISCUSSION}

\section{Confirmation of the presence of greening in infected trees}

The trees were identified during survey and tested for the presence of greening inoculum by PCR. It was found that the pathogen was found from all the trees (Figure 1). The details of the PCR will be given in subsequent results. The leaves from these trees were collected and used in further experiments.

\section{Graft transmission}

The six-PCR positive trees (Figure 2) grafted on mandarin plants showed typical greening symptoms in 3 to six months after grafting. The new leaves showed yellowing followed by mottling of leaves. The grafted plants showed amplification of greening pathogen in PCR when tested after six months. However, since the studies were planned with a view to develop PCR diagnostic from field trees, enough leaf material was collected from individual PCR positive trees in the fields and stored at $80^{\circ} \mathrm{C}$ in deep freeze and was used in subsequent studies. One negative control was kept.

\section{DNA isolation from citrus tissue}

Results (Table 2) reveal that the average DNA yield of three samples isolated by sodium sulphite method was $1216.16 \mathrm{ng} / \mu \mathrm{l}$. It was slightly higher in nucleic acid membrane method with average of $1429.16 \mathrm{ng} / \mu \mathrm{l}$. However, yield of DNA by kit method was only $159 \mathrm{ng} / \mu \mathrm{l}$.

\section{Determination of quality of DNA isolated by three methods}

Results (Table 3 ) indicate that average value of DNA extracted by sodium sulphite method was 1.50 and by commercial kit was 1.54 while it was only 1.14 with DNA extractable by nucleic acid membrane method. The presence of greening disease in India was discovered by Fraser et al. (1966). Since then, the disease has been reported from various parts of the country (Ahlawat, 1997). In the absence of reliable diagnostic reagents and tools like electron microscope, the actual incidence and distribution of citrus greening bacterium (CGB) in India has not been investigated till 1991. During the period from 1991 to 1996 , 51and 339 trees from 98 orchards 

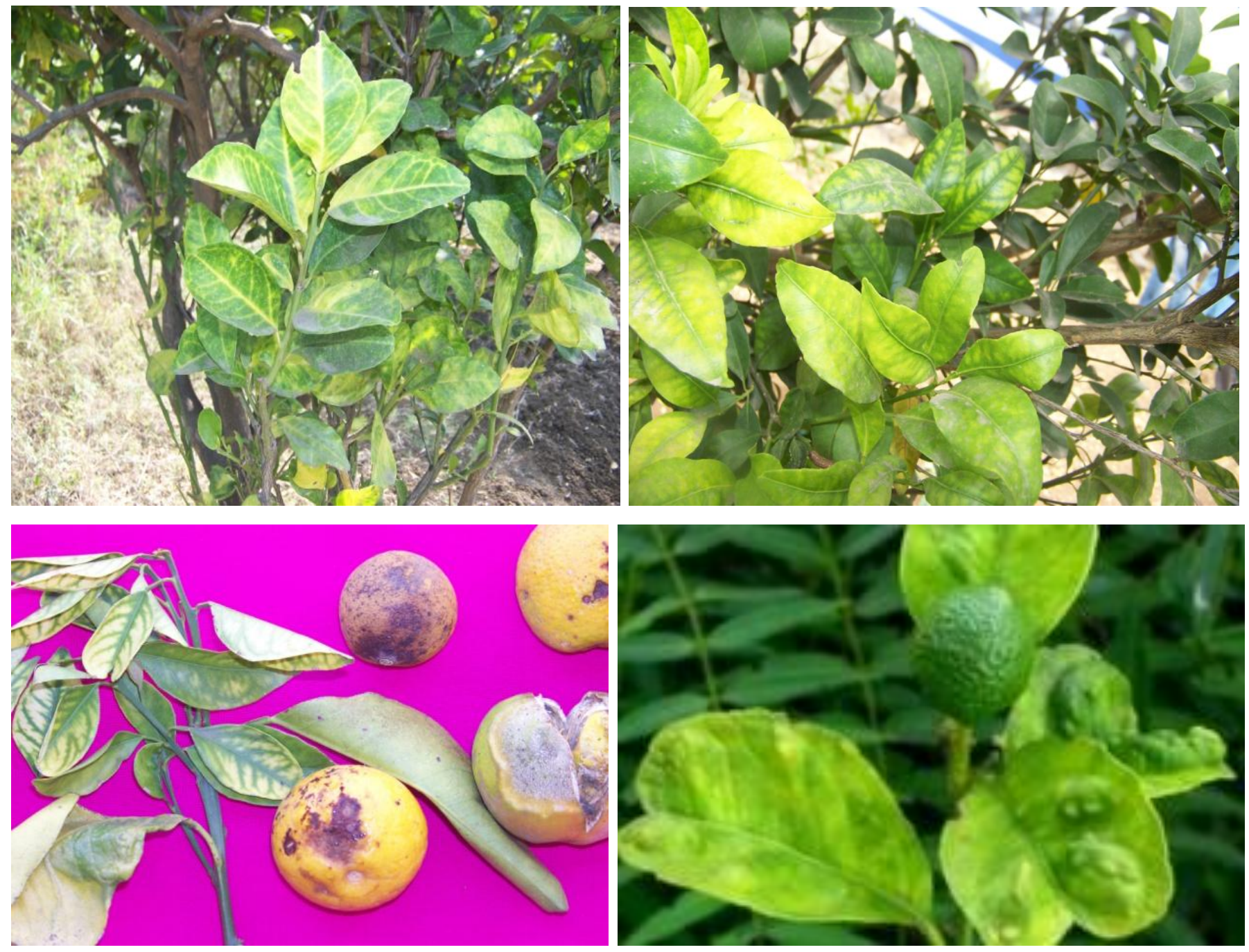

Figure 1. Confirmation of the presence of citrus greening in infected trees.

were tested which were collected from eight different states of India and presence of CGB was confirmed by electron microscopy, immunoflorescence and DNA-DNA hybridization technique (Ahlawat and Pant, 2003). Subsequently, the PCR technology was developed for detection of CGB (Jagouiex et al., 1996; Tian et al., 1996; Harakava et al., 2000; Hocquellet et al., 2000). However this PCR technique was used for the first time to detect greening disease in citrus in India by Ahlawat et al. (2003). Serological-based diagnosis was not found as effective as it requires a panel of strain-specific monoclonal antibodies and due to the sacrifice of animals in production of monoclonal antibodies. The nucleic acid hybridization technique required radioactive material and is not advisable if other efficient and reliable techniques like PCR are available. Therefore, during the present investigation, the information has been developed on suitability and reliability of PCR technique for detection of greening bacterium as a routine procedure of indexing. There was little information available for the charac- terization of Asian greening bacterium by amplification, cloning and sequencing although reports are there for African greening bacterium (Planet et al., 1995).

During the present study, trees of mandarin of the age of 3 to 10 years were periodically surveyed at the orchards of Marathwada region. A very high incidence of $65.00 \%$ was observed. The greening incidence information in these investigations was determined on the basis of typical symptoms of greening disease in field trees and the analysis of six candidate trees by PCR using protocol. Six trees were identified based on PCR reaction for these studies. The leaves from these trees were collected and preserved at $80^{\circ} \mathrm{C}$ in deep freeze for the use in various experiments. The graft transmission was also obtained from this tree on Mosambi seedling after three to six months of grafting. However, only four plants out of six grafted, showed positive amplification in PCR. This may happen because the scions grafted on these two PCR negative plants may not be having the required quantity of pathogen required for graft trans- 


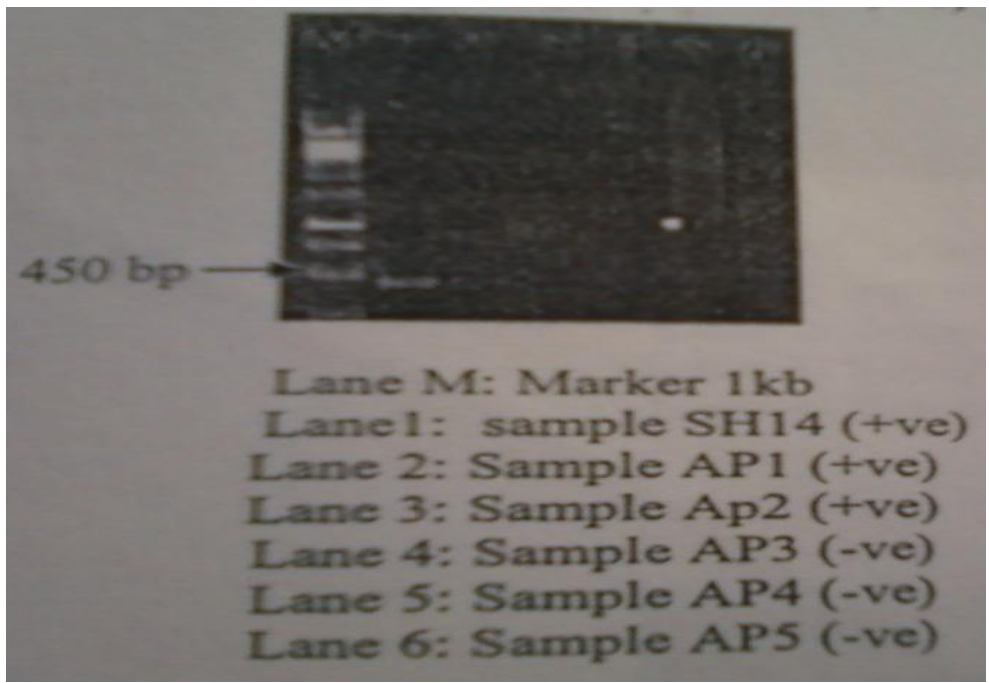

Figure 2a. Agarose gel electrophoresis ofDNA amplified with primers. Lanes 1 to 6 contain PCR reactions from six different seedlings. M, $1 \mathrm{~kb}$ ladder.

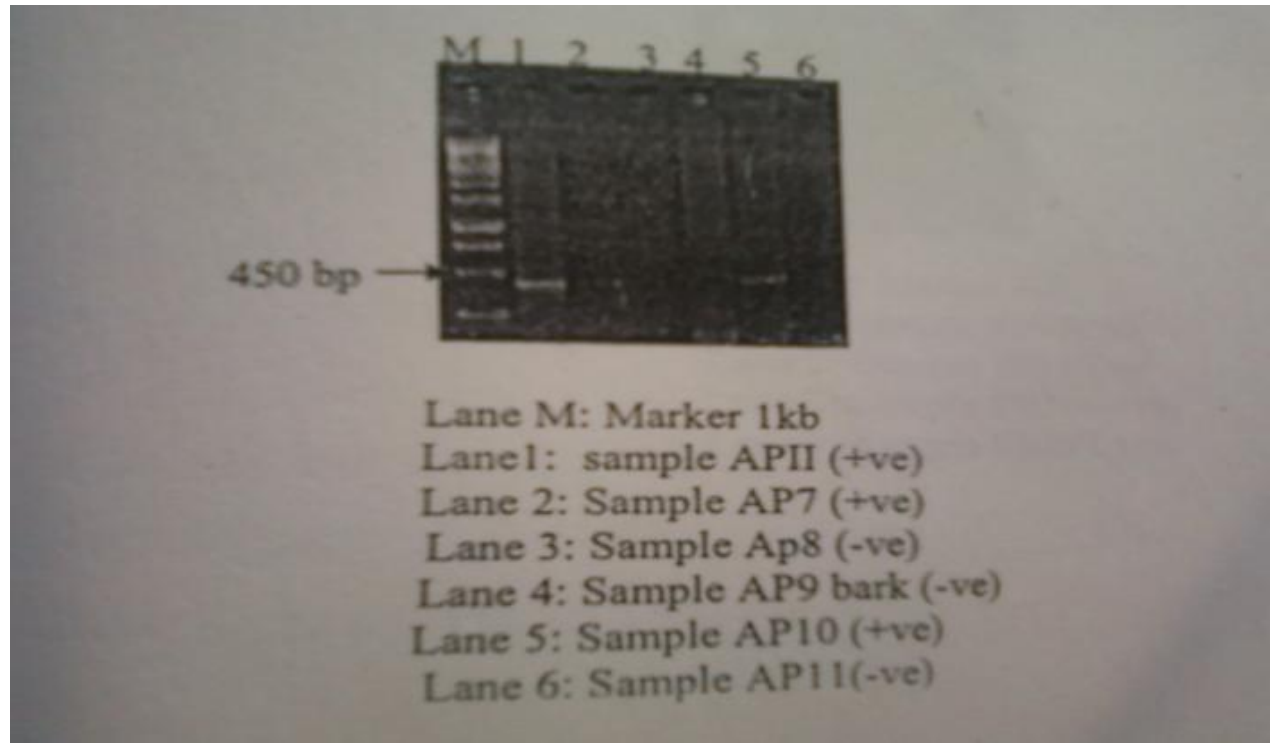

Figure 2b. PCR products were separated on a $2 \%$ agarose gel and stained with ethidium bromide.Lanes 1 to 6 contain PCR reactions from six different seedlings.M, $1 \mathrm{~kb}$ ladder.

mission. It is known that the distribution of greening bacterium is erratic in the plant tissues (Varma et al., 1993) and this could be the reason of non transmission in plants by grafting. Since the studies were planned with a view to standardize and validate PCR diagnostics in field trees, the materials collected from six identified greening positive trees were used in these studies.

Three components are important for detection of pathogen in PCR. They are: nucleic acid isolation and its quantity and quality, primer designing synthesis and its evaluation, evaluation of polymerase enzymes for PCR amplification. In the present study, all the three steps were standardized. The DNA was isolated by three methods; sodium sulphate (Baranwal et al., 2003), cetyl trimethyl ammonium bromide (CTAB) method (Murray and Thompson, 1980) and commercial kit obtained from QIAGEN Germany. The leaf material collected from six PCR positive trees was used in most of the experiments. The quantity of the DNA obtained from six samples was more CTAB method followed by sodium sulphite method. Similar results were obtained by Baranwal et al. (2003) where commercial kit and CTAB method were used while working with potato and a cherry virus and with citrus yellow mosaic virus. However, the yield of DNA by com- 
Table 2. The quantity of DNA obtained from three infected sample by 3 method of DNA isolation.

\begin{tabular}{cccc}
\hline Sample & Sodium sulphite $(\mathbf{n g} / \boldsymbol{\mu l})$ & Commercial kit $(\mathbf{n g} / \boldsymbol{\mu l})$ & Nucleic acid $(\mathbf{n g} / \boldsymbol{\mu l})$ \\
\hline 1 & 1531.0 & 123.25 & 535.0 \\
2 & 2864.0 & 201.00 & 1056.0 \\
3 & 986.5 & 165.00 & 2113 \\
4 & 796.0 & 124.75 & 1053 \\
5 & 552.0 & 207.50 & 2212 \\
6 & 568.0 & 136.50 & 1606 \\
Average & 1216.16 & 159.60 & 1429.16 \\
\hline
\end{tabular}

Table 3. Quality comparison of three methods $\left(A_{260} / A_{280}\right)$.

\begin{tabular}{cccc}
\hline Sample & Sodium sulphite & Commercial kit & Nucleic acid membrane \\
\hline 1 & 1.06 & 1.05 & 1.14 \\
2 & 1.53 & 2.86 & 1.02 \\
3 & 1.13 & 1.05 & 1.01 \\
4 & 2.54 & 1.44 & 0.99 \\
5 & 1.76 & 1.60 & 1.55 \\
6 & 1.01 & 1.27 & 1.15 \\
\hline
\end{tabular}

mercial kit $(159.60 \mathrm{ng} / \mathrm{ml})$ was much less as against sodium sulphate method $(1216.16 \mathrm{ng} / \mathrm{ml})$. The quality of DNA obtained by all the three methods was assessed by calculating A260/A280/260 ratio. It was observed that the quality obtained by sodium sulphite method and commercial kit was almost at par (1.50 and 1.54, respectively). Although the best quality of DNA is known with the $A_{260} / A_{280}$ of 1.8. However, this ratio has not been achieved with the any of the methods. But the satisfactory amplification was obtained even of the DNA extracted by sodium sulphite method with the $A_{260} / A_{280}$ ratio of 1.50 . That is why this method was used in the experiment too. Since the quantity and quality of DNA isolated by sodium sulphite method was found to be better, this method was preferred over the methods of commercial kit and nucleic acid membrane method.

In the present studies, primers were not designed, but they were synthesized based on the published sequence data by Harakava et al. (2000). Three parts of primers from conversed region of ribosomal $\beta$ operon gene and $16 \mathrm{~S}$ rDNA were gotten synthesized by Sigma, Germany. These three pairs of primers were designated as A, B, C which provide amplicon size as 1160,703 and $450 \mathrm{bp}$, respectively. These three sets of primers were evaluated. The comparative studies show that $C$ sets of primer (450 bp) was superior than $A$ and $B$ as it could amplify the DNA upto $100 \mathrm{pg}$ as against only 100 and $10 \mathrm{ng}$ dilution of DNA with $A$ and $B$ sets of primers. The evaluation was also done using Taq and Klen Taq enzymes and Klen Taq as was expected gave better intensity of the bands obtained in $1 \%$ agarose gel. Similar evaluation for primer has also been used by other researchers with different viruses (Singh and Nie, 2003; Harakava et al., 2000; Das,
2004; Manjunath et al., 2008; Baranwal et al., 2007; Khairulmazmi et al., 2008; Naoya et al., 2008; Thiara et al., 2009; Albrecht and Kim Bowman, 2009; Deng et al., 2012).

In this study, the DNA extraction method by sodium sulphite, Klen Taq enzyme and $450 \mathrm{bp}$ set of primers were identified to give best amplification in PCR system of diagnosis. Using these protocols, samples from mandarin tree collected in March, 2010 were analyzed in PCR using combination of all the three standardized steps. It was found that for the amplification of DNA isolated out of 20 samples, 15 and 19 were PCR positive during the month of October and March, respectively. During the survey of greening diseases $65.00 \%$ of incidence of disease was observed while for the testing trees for the presence of greening bacterium in PCR, 15 were positive during October and 19 in March indicating much higher incidence of disease with PCR testing. The results suggest that the PCR is a reliable technique for detection of greening bacterium as against the diagnosis based on visible symptoms. It was therefore evident that protocols developed in this study can detect greening bacterium in field trees irrespective of the season and the concentration of pathogen in the host. However, since more samples showed the presence of greening bacterium during March, the samples for detection of the bacterium should be taken in March to get maximum detection.

Detection of viruses and virus like pathogens as by PCR technique are gaining importance over the other technique as it is comparatively sensitive and reliable and can detect the pathogen even at a very low concentration upto $0.1 \mathrm{pg}$. The concentration of greening bacterium is 
very low in sieve tubes and distribution is also uneven (Varma et al., 1993) and it is important that the samples are taken from different tree branches. The technology of PCR detection of greening bacterium developed during present investigation is new and validated for the first time in India. It will be very useful for field diagnosis of greening disease in planting material. These studies will also be useful in plant quarantine for export and important for citrus germplasm. The technology developed is cost effective and highly reliable for indexing bud wood certification programmes in citrus in India elsewhere. Polymerase chain reaction is the main tool for diagnosis of liberibacters and other nonculturable phloem,-restricted pathogens. Molecular detection based on DNA sequences is highly sensitive and is not dependent on the viability of the organism. Provided that PCR products detected during the early development of citrus seedlings are not the result of cross contamination, detection suggests that bacterial cells or bacterial DNA must somehow be translocated into the tissue of the developing seedling. The detection of citrus greening bacterium is of considerable importance due to its widespread occurrence and its negative effects on quality and quantity of citrus fruits and health of the citrus trees. Its detection by quicker and reliable methods has been shown by Harakava et al. (2000) and Baranwal et al. (2004).

\section{REFERENCES}

Ahlawat YS (1997). Viruses, greening, bacterium and viroids associated with citrus (Citrus sp.) decline in India. Ind. J. Agric. Sci. 67:51-57.

Ahlawat YS, Baranwal VK, Mazumdar S (2003). First report of citrus greening disease and associated bacterium. Candidatus Liberibacter from Bhutan. Plant Disease 87:448.

Ahlawat YS, Pant RP (2003). Major virus and virus-like diseases of citrus in India, their diagnosis and management. Ann. Rev. Plant Pathol. 2:447-474.

Albrecht U, Bowman KD (2009). Candidatus Liberibacter asiaticus and huanglongbing effects on citrus seeds and seedlings. HortScience 44(7):1967-1973

Baranwal VK, Gupta KN, Singh RP (2007). Polymerase chain reaction detection of greening bacterium (Candidatus Liberibacter asiaticus) and citrus mosaic virus in citrus tissues, by means of a simplified template preparation protocol. Can. J. Plant Pathol. 29:190-196.

Baranwal VK, Majumdar S, Ahlawat YS, Singh RP (2003). Sodium sulphite yields improved DNA of higher stability for PCR detection of citrus yellow mosaic virus from citrus leaves. J. Virol. Methods 112:153-156.

Baranwal VK, Mazumdar S, Singh J, Suryanarayana V, Ghosh DK, Ahlawat YS (2004). PCR detection of Candidatus Liberibacter asiaticus, the agent of Huanglongbin or greening disease in citrus. Ind. Phytopath. 57:164-68

Das AK (2004). Rapid detection of Candidatus Liberibacter asiaticus, the bacterium associated with citrus huanglongbing (greening) disease using PCR. Curr. Sci. 87(9):1183-1185.

Deng Xiao-ling, Gao Yi-di, Chen Jian-chi, Pu Xue-lian, Kong Wei-wen and Li Hua-ping (2012). Curent Situation of "Candidatus Liberibacter asiaticus" in Guangdong, China, Where citrus huanglongbing was first described. J. Integr. Agric. 11(3):424-429.

Fraser LR, Singh D, Capoor SP, Nariani TK (1966). Greening virus, the likely cause of citrus dieback in India. FAO Plant Prot. Bull. 14:127130.
Harakava R, Morais LJ, Ochasou J, Manjunath KL, Febres VJ, Lee RF, Niblett GL (2000). Improved sensitivity in the detection and differentiation of citrus huanglongbing bacteria from South Africa and the Phillippines. In. Proc., $14^{\text {th }}$ Conf., IOCV. IOCV. Riverside, California. pp. 195-199.

Hocquellet A, Bove JM, Garnier M (2000). Isolation of Candidatus liberibacter genes by RAPD and new PCR detection technique. In : Proc. $14^{\text {th }}$ Conf. IOCV, IOCV Riverside, California. pp. 363-368.

Jagouiex S, Bove JM, Grnier M (1996). PCR detection of the two candidates liberobacter species associated with greening diseases of citrus. Molecular Cell. Probes 10:43-50.

Khairulmazmi A, Kamaruzaman S, Habibuddin H, Jugah K, Syed OSR (2008). Occurrence and Spread of Candidatus Liberibacter asiaticus, the causal agent of huanglongbing disease of citrus in Malaysia. Res. J. Agric. Biol. Sci. 4(1):103-111.

Korsten LG, Sanders M, Su HJ, Garnier M, Bove JM, Gotze JM (1993). Detection of citrus greening infected citrus in South Africa using DNA probes and monoclonal antibodies. In Proc. $12^{\text {th }}$ Conf. IOCV, IOCV, Riverside. pp. 224-232

Manjunath KL, Halbert SE, Ramadugu C, Webb S, Lee RF (2008). Detection of 'Candidatus Liberibacter asiaticus' in Diaphorina citri and its importance in the management of citrus huanglongbing in Florida. Phytopathology 98:387-396.

Naoya U, Shinji K, Hiroyuki M, Takashi U, Osamu T, Teruo S (2008). Rapid and sensitive detection of "Candidatus Liberibacter asiaticus" by cycleave isothermal and chimeric primer-initiated amplification of nucleic acids. J. Gen Plant Pathol. 74:151-155

Planet PS, Jagoueix Bove JM, Garnier M (1995). Detection and characterization of the African citrus greening Liberobacter by amplification, cloning and sequencing of rplKJL-ropBC operon. Curr. Microbiol. 30:137-141.

Singh RP, Nie X (2003). Multiple virus and viriod detection and strain seperation via multiplex riverse transcription-polymerase chain reaction. Can J. Plant. Path. 25:127-134.

Thiara SK, Singh PP, Kang SS (2009). PCR based detection of greening bacterium (Candidatus Liberibacter asiaticus) in citrus. Plant. Dis. Res. 24 (1):48-50.

Tian Y, Ke S, Ke C (1996). Polymerase chain reaction for detection and quantification of liberiobacter asiaticus, the bacterium associated with Huangolongbing (Greening) of citrus in China. In Proc. $13^{\text {th }}$ Conf., IOCV. IOCV Riverside, California. pp. 252-257

Varma A, Ahlawat YS, Chakraborty NK, Garnier M, Bove JM (1993). Detection of greening BLO by electron Microscopy, DNA hybridization in citrus leaves with and without mottle from various regions in India. In Proc. $12^{\text {th }}$ Conf., IOCV Riverside, California. pp. 280-285. 